"The Re-colonisation of a Burnt Patch at Cissbury" was the title of a paper by Mr. B. T. Lowne. The Jubilee and Coronation bonfires of 1935 and 1937 left a scar more than $50 \mathrm{ft}$. in diameter, with a thickness of some 8 inches of ash. These sterilized the soil to some depth. The creeping thistle was the first plant to establish itself, followed by the black. berry. Several plants not native to the spot made an appearance, notably the evening primrose, but this may have been carried to the spot in the footwear of one of the builders of the fire. Late visits to the spot showed that thirty-nine species of plants have established themselves and downland plants are gradually again growing there. Mr. Lowne also exhibited a hybrid between two species of geranium which he discovered on the Downs, and found that the hybrids had bred true, many specimens having been found.

Miss E. Gerard, curator of the Worthing Museum, showed maps of Sussex from the earliest times of map-making, including a copy of the Armada map and another of the Palmer map of 1587. The many changes in the coast-line were clearly shown.

Other papers of a high order were contributed, amongst them being "Geology of the Selborne District", by Dr. C. P. Chatwin, "Recent Progress in the Study of Insect Migration", by Dr. C. B. Williams, "The Coastal Plain", by Mr. C. T. Gaster and Mr. E. C. Martin, "British Herbals of the 17th Century", by Dr. T. A. Sprague, and "A Proposed Survey of Chalk Springs and Bournes", by Mr. F. H. Edmunds.
It was announced that John Selden's cottage, known as 'Lacies', at Salvington, where Selden was born in 1584, had been offered as a freehold to the Worthing Corporation by Mr. Alfred W. Oke.

The Union having been requested to arrange for the delivery of the Alexander Pedler Lecture of the British Science Guild, now incorporated in the British Association, this was entrusted to Prof. H. L. Hawkins, who took as his subject "Humanity in Geological Perspective". After discussing many outwarn theories, he said that he suspected that true geological knowledge is even now held but by the few, and is brushed aside by those who have it but do not wish to own its teachings. Truth, chivalry and kindness are, he said, inconsistent with the struggle for existence, but nevertheless the 'idealist', who faces noble thoughts, is a man. "Men can learn ; their capacity for appreciating wisdom shows that its acquisition is not beyond their powers. And wisdom, which makes men human, is better than the rubies of material success that may leave him bestial."

The excursions were very varied, suiting all tastes, visits to Cissbury, Amberley, Sompting, the Broadwater Waterworks, the Angmering Roman Villa, Swanbourne and the Arun, and the Highdown House Gardens having been arranged.

A reception at the Town Hall was given to members by the Mayor and Mayoress, Councillor and Mrs. W. C. Birkett, whose co-operation in making the Congress a success was greatly appreciated by the Union.

\title{
Scientific and Industrial Research in Australia
}

$\mathrm{T}$ HE eleventh annual report of the Council for Scientific and Industrial Research, Commonwealth of Australia, which covers the year ended June 30, 1937, refers to the establishment of a Fisheries Section to conduct researches into Australian Fisheries problems. This is at present housed in temporary quarters but a properly trained staff is being built up while the problems determining the location of the research station are being reviewed and an investigation vessel is under construction. Experimental flights have already indicated that aerial observations can considerably assist the work of the investigation vessel. Considerable progress was also made during the year in the provision of adequate laboratory facilities. The Forest Products Laboratory was officially opened on April 7, 1937; the Viticultural Research Station, Merbein, has been occupied and it was anticipated that the headquarters laboratories and experimental cool stores of the Section of Food Preservation and Transport and the new Animal Health Laboratory would be ready for occupation at the end of 1937.

The Division of Plant Industry has continued its investigation into plant pasture problems as well as of physiological diseases of fruit in the field and disorders following storage. Evidence has been obtained that high soil temperatures increase resistance to pest-seedling development of flag-smut in certain varieties of wheat and lowers it in others. In the fumigation of seed beds for control of downy mildew or blue mould of tobacco, benzene vapour always gave the best results and attention is being turned to control under field conditions. The Division of Economic Entomology has given much time to the sheep blowfly pest, including studies both of the sheep and the flies as well as the prevention and treatment of strike. Search has been made for substitutes for lead arsenate in insecticides for codling moth sprays, and a good deal of the Division's time has been occupied with work on the biological control of noxious weeds, as well as on chemical methods of weed control. Investigations by the Animal Health laboratories have again ranged over a wide field including bovine mastitis, studies in fleece chemistry and fibre measurement, fertility in sheep, dairy products research, and in addition the Animal Nutrition Laboratory at Adelaide has been responsible for investigations on phosphorus metabolism of sheep and on coast disease.

The Forest Products Division's investigations also cover a wide field from the seasoning of timber, timber physics, wood structure and utilization to the preservation of wood where the value of arsenicals as termiticides in Australia and of sodium silicofluoride for protection against Lyctus attack has been es. tablished. Many important investigations have also been carried out at the Viticultural Research Station on irrigation and drainage as well as by the Food Preservation Section, including investigations on chilled beef such as loss of bloom, on diseases of bananas and their control, citrus packing house problems, including the colouring of citrus fruits, and problems relating to the storage and diseases of apples, pears, plums, peaches, etc. 